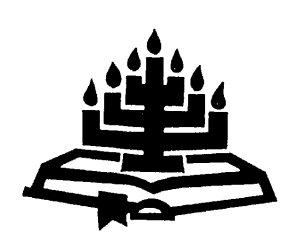

\title{
Die prediking van hoop aan getraumatiseerdes in die huisgesin van God. Prakties-teologiese perspektiewe in die lig van Hebreërs
}

\author{
C.J.H. Venter 1 \\ Vakgroep Praktiese Teologie \\ Skool vir Kerkwetenskappe \\ Potchefstroomse Universiteit vir $\mathrm{CHO}$ \\ POTCHEFSTROOM \\ E-pos: kwscjhv@puknet.puk.ac.za
}

Abstract

The preaching of hope to traumatized people in the household of God. Practical-theological perspectives in the light of Hebrews

This article focuses mainly on two prominent areas of research. Firstly, applicable basis-theoretical material from Hebrews on issues of preaching hope in the household of God is selected and analysed. Secondly, the concept of trauma is outlined. After this the DSM-IV criteria list is utilized to establish certain psychological patterns in the life of people experiencing trauma. Finally, practice-theoretical perspectives are indicated for preaching hope to traumatized people in the household of God.

\section{Opsomming}

Die prediking van hoop aan getraumatiseerdes in die huisgesin van God. Prakties-teologiese perspektiewe in die lig van Hebreërs

In hierdie artikel word hoofsaaklik op twee navorsingsgebiede gefokus. Eerstens word toepaslike basisteoretiese materiaal uit Hebreërs byeengebring en ontleed. Prediking in God se huisgesin en dimensies van hoop vir lede van die huisgesin ontvang aandag. Vervolgens word die konsep van trauma op metateoretiese vlak ondersoek. Die DSM-IV kriterialys word gebruik om bepaalde psigologiese patrone by getraumatiseerdes vas te stel. Laastens

\footnotetext{
1 Met erkenning aan die werk van Griffel van Wyk as navorsingsassistent.
} 
word op grond van die navorsing op basisteoretiese en metateoretiese vlakke praktykteoretiese perspektiewe gebied op die prediking van hoop aan getraumatiseerde en aan die huisgesin van God.

\section{Inleiding}

\subsection{Definisie}

Trauma word op meer wyses gedefinieer. Bisbey en Bisbey (1998:27) formuleer dit egter soos volg:

A trauma is any event or experience that is outside the person's usual or ordinary experience and expectations about the way in which the world works and/or the way in which people treat each other.

As die brein vergelyk word met 'n informasie-prosesseringsisteem, kan 'n trauma volgens Bisbey en Bisbey (1998:23) beskryf word as 'n oorweldigende invoer van data, wat van so groot omvang is dat dit die vermoë van die individu om sy aandag selektief te rig, omseil. Hierdie nuwe invloei van data word dan glad nie geprosesseer nie, en word eenmalig ongesistematiseerd gelaat. Hierdie data vind dan geen plek in die bestaande verwysingsraamwerk nie en word daarom nie verstaan nie. lets wat dus nie verstaan of verwerk kan word nie, en 'n dreigende selfs noodlottige - gevaar inhou, kan 'n traumatiserende effek hê op die individu.

Die "Diagnostic and Statistical Manual of Mental Disorders - IV Edition" (DSM-IV-TR, 2000:463) definieer trauma soos volg:

... traumatic stressor involving direct personal experience of an event that involves actual or threatened death or serious injury, or other threat to the physical integrity of another person; or learning about unexpected or violent death, serious harm, or threat of death or injury experienced by a family member or other close associate. The person's response to the event must involve intense fear, helplessness, of horror (or in children, the response must involve disorganized or agitated behavior).

By hierdie definisies word in die artikel aangesluit.

\subsection{Aktualiteit}

Die aktualiteit van hierdie onderwerp blyk onder andere uit resente statistiek oor geweld in Suid-Afrika. Projeksies dui daarop dat, wat geweld en misdaad betref, 1600 uit elke 100000 mense slagoffers sal 
wees van gewelddadige misdaad in die volgende jaar. Dit beteken een uit elke 63 mense. Van hierdie gevalle sal 59 voorvalle van moorde wees, 68 poging tot moord, 168 diefstal met verreikende gevolge, 252 verkragtings, 565 aanrandings met die intensie van ernstige besering, en 488 algemene aanrandings. Elke 47 minute sterf een persoon op SuidAfrikaanse paaie. Vir elke persoon wat aan trauma (fisiologies)-verwante redes beswyk, word 85 ander met beserings in die hospitaal opgeneem (Foa, 2001) Dit is noodsaaklik om hierby te voeg dat alle fisiologiese trauma egter gepaard gaan met psigologiese trauma (Joseph, Williams \& Yule, 1997:51-67).

Vanuit mediese en psigologiese hoek is heelwat navorsing oor trauma en die hantering van trauma reeds gedoen (Foa, 2001; Hyer, 1994; Howard, 2000; McFarlane, Shalev \& Yehuda, 2000). Ook vanuit die oogpunt van herderlike bediening aan getraumatiseerdes is reeds ondersoekwerk gedoen (vgl. Louw, 1994:109-191; Van Dyk, 2001:289). Wat die prediking in traumasituasies betref, is daar egter leemtes in homiletiese navorsing. Weliswaar word gefokus op aspekte soos prediking in bepaalde lydensituasies (vgl. Armstrong, 1990:114), en as 'n klein onderdeel word prediking in 'n tyd van trauma betrek (vgl. Louw, 1985: 106-141), maar die prediking van hoop, spesifiek aan getraumatiseerdes in die huisgesin van God, het nog nie genoeg aandag in homiletiese werke ontvang nie.

'n Verdere rede vir die aktualiteit van hierdie ondersoek is dat hier gefokus gaan word op prediking van hoop, spesifiek soos dit in Hebreërs na vore kom. Hebreërs het wat wetenskaplike ondersoek betref, reeds aan die orde gekom in ondersoeke, onder andere na prediking en gesindheidsverandering (Kruger, 2002), en navorsing oor verklarende prediking (Venter, 2001), maar nie spesifiek met die oog op die prediking van hoop aan getraumatiseerdes nie.

\subsection{Ondersoekveld}

Die ondersoek word dus onderneem om 'n nadere antwoord te omlyn op die vraag: Hoe kan die prediking van hoop aan getraumatiseerdes in die huisgesin van God meer tot sy reg kom? Die ondersoekvelde behels die metateoretiese veld van post-traumatiese stres, en die ontwikkeling daarvan tot sindroom, soos dit in die Sielkunde na vore kom, asook die basisteoretiese veld wat gegewens uit Hebreërs ontgin. As slotsom word bepaalde praktykteoretiese perspektiewe gebied op die prediking van hoop aan getraumatiseerdes binne 'n gemeente. 


\subsection{Ondersoekmetode}

Die metode behels die analise en interpretasie van toepaslike gegewens in die betrokke ondersoekvelde.

\section{Basisteoretiese perspektiewe uit Hebreërs op prediking}

\subsection{Hebreërs}

Die skrywer van Hebreërs, asook die gemeenskap aan wie dit eerste gerig is, is grootliks onbekend (Stedman, 1991:11; DeSilva, 2000:1). Al kan bepaalde feite soos die outeur of spesifieke gehoor nie vasgestel word nie, kan daar uit die teks 'n aantal afleidings gemaak word om 'n duidelike gevolgtrekking te kan maak oor die outeur se doel met die brief, asook die gehoor, hulle geskiedenis/agtergrond, en hul konteks (DeSilva, 2000:1). Dit dra by tot die verstaan van die teks in 'n bepaalde afgeleide konteks.

Alhoewel kenners onseker is oor waar die oorspronklike lesers van Hebreërs hulself bevind het, is dit duidelik dat hulle grootliks bestaan het uit tweedegeslag-Christene. Hulle vroeëre leiers is al oorlede of weg (13:7). Hulle het ook al 'n geruime tyd van Christus getuig (5:12) en daar is getuienis van hul standvastige geloof (10:32-34). Toe Hebreërs egter geskryf is, was hulle in 'n toestand van kleinmoedigheid en geestelike armoede. Sommige het al begin wegbly van die samekomste af (10:25). Verder het baie mense toenemende teenstand onder hulle Joodse families en vriende ervaar omdat hulle in Jesus glo (Stedman, 1991:1213; vgl. DeSilva, 2000:7-11). Die Hebreërs-brief word dus aan hulle gerig as bemoediging in hul beproewing.

\subsection{Kernbegrippe wat gebruik is om prediking in Hebreërs uit te druk}

- $\lambda \alpha \beta$ ov̂ $\alpha \lambda \alpha \lambda \epsilon \hat{\imath} \sigma \theta \alpha \iota$ - ("begin om vertel te word") - Hebreërs 2:2, 3

- 'A $\pi \alpha \gamma \gamma \in \lambda \omega$ - ("inlig"; "bekend maak") - Hebreërs 2:12

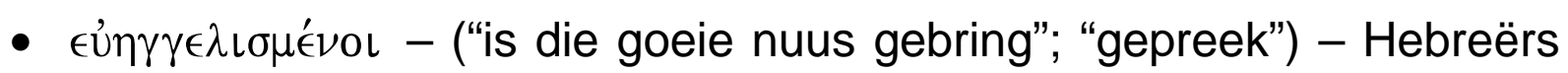
$4: 2$

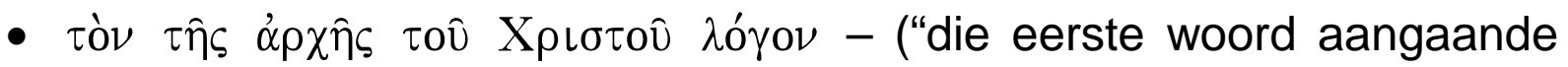
Christus") - Hebreërs 6:1

2.2.1 $\lambda \alpha \beta$ ov̂ $\alpha \lambda \alpha \lambda \epsilon \hat{\imath} \sigma \theta \alpha \iota$ - ("begin om vertel te word") - Hebreërs 2:3

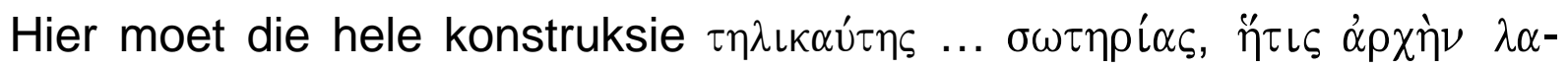

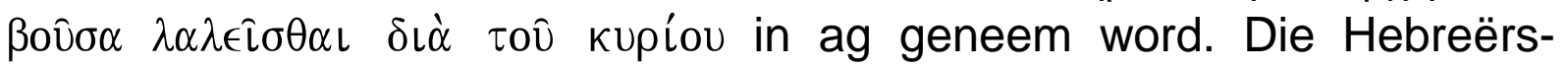
skrywer is besig om te beklemtoon dat ag geslaan moet word op die 
verlossing soos dit die eerste keer deur die Here (Jesus) verkondig is (Montefiore, 1964:53). Hy noem dan dat die wet, soos deur engele gekommunikeer, onwrikbaar was en waardig is om nougeset na te volg. Maar nou is die boodskap van die groot verlossing soveel meer betroubaar en noodsaaklik om op ag te slaan, want dit is nie die engele wat dit aan die mens oorgedra het nie, maar Jesus self het begin ( $\dot{\alpha} \rho \chi \dot{\eta} \nu)$ om dit aan die mens bekend te maak. Die straf op die mense wat die boodskappe van die engele verontagsaam het is groot, en soveel meer ook dié wat dan die boodskap van Christus self verontagsaam (DeSilva, 2000:104).

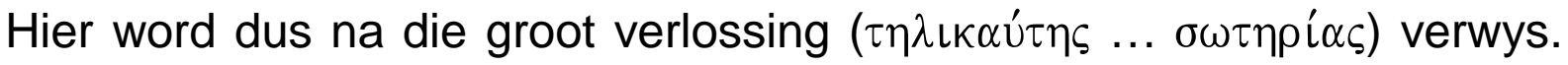
In hierdie groot verlossing is die inisiatief tot verkondiging geneem deur Jesus self (Rienecker \& Rogers, 1980:667). Die boodskap van die groot verlossing eis dus soveel meer gesag en noodsaak om aangehoor te word, omdat Jesus self die een is wat dit hier op aarde begin verkondig het. Inbegrepe in die boodskap van verlossing is noodwendig die boodskap van hoop.

Die stam van die werkwoord "verkondig" ( $\lambda \alpha \lambda \in \hat{\imath} \sigma \theta \alpha \iota$ - praesens infinitief passief), is $\lambda \alpha \lambda^{\prime} \epsilon \omega$. Hierdie woord kan dus vertaal word met "om te praat", "om te vertel", "om te sê" en word in die Ou sowel as die Nuwe Vertaling met "verkondig" vertaal. Die frase kan dus letterlik vertaal word as: "Die inisiatief is geneem om dit (die groot verlossing) te verkondig deur Jesus." Hy is dus die eerste prediker en verkondiger. Christus het begin, en die apostels het Hom nagevolg. Johannes het wel die weg voorberei, maar Jesus was die eerste prediker wat die evangelie verkondig het. Die feit dat Jesus dan die eerste prediker van die saligheid was, maak dit soveel meer heerlik, maar heg ook 'n soveel groter verantwoordelikheid aan die taak van prediking (Stedman, 1991: 34). Die feit dat dit Jesus was wat hoop eerste verkondig het, vergroot ook die hoop waarmee die lesers aan die saligheid kan vashou soveel meer (Grosheide, 1955:77).

\section{Basisteoretiese afleiding}

- Christus was die eerste een wat die groot saligheid op aarde aan die mense verkondig het.

- Die feit dat Hy die eerste verkondiger daarvan is, maak die saligheid soveel meer heerlik en betroubaar. Juis daarom bied die verkondiging van die groot saligheid soveel meer hoop aan getraumatiseerdes.

\subsection{2 'A $\alpha \alpha \gamma \in \lambda \hat{\omega}$ - ("inlig"; "bekend maak") - Hebreërs 2:12}

Die skrywer is hier besig om Christus te beskryf as een wat bo die engele is en wat in 'n besondere verhouding staan met die mens. 
Christus word beskryf as die Priester wat medelye kan hê. Dit gaan verder daaroor dat Jesus hom nie skaam vir die mense nie, want Hy noem hulle immers broers, omdat hulle van dieselfde Vader kom (Crouch, 1983:45). Die skrywer haal die sinsnede aan uit Psalm 22:23 "Ek wil u Naam aan my broers vertel, in die vergadering U prys."

Die oorspronklike teks in Psalm 22 wat aangehaal word, asook soos dit in Hebreërs gebruik word, vertel van die koning wat baie lyding verduur het (vroeër in die psalm) en wat nou liedere van lof sing in gemeenskap met die broers wat saam is vir aanbidding. Hy is dus deel van hulle, en deel met hulle. In hierdie éénwees en in hulle teenwoordigheid in die samekoms verkondig Hy dan aan sy broers (DeSilva, 2000:116). 'n Baie innige verhouding bestaan dus, hulle het dieselfde Vader. Hy praat met of verkondig aan mense asof hulle sy broers is, Hy doen dit binne 'n intieme verhouding (Stedman, 1991:42).

Die skrywer van die brief wil nou met hierdie aanhaling wys dat Jesus een geword het met sy volk ... Hy is een met hulle (Stedman, 1991:42).

\section{Basisteoretiese afleiding}

- Jesus sien Homself in sy verkondiging as broer van dié aan wie Hy verkondig. Hy staan nie in 'n kliniese afstandsverhouding nie, maar in 'n broerverhouding, innig en op dieselfde vlak.

- Verkondiging wat die voorbeeld van Christus volg, geskied op 'n intieme wyse waar verkondiger en hoorder op gelyke vlak verkeer.

- Dit is dus belangrik dat die verkondiger vanuit 'n intieme verhouding met die traumalyer hoop moet bedien.

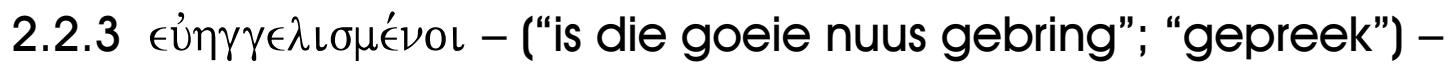 Hebreërs 4:2}

Hierdie woord is 'n perifrastiese perfektum partisipium passief. Die perifrastiese perfektum lê klem op die voortgang van die historiese feit van verkondiging (Crouch, 1983:108). Die evangelie is aan hulle verkondig, maar word steeds voortdurend aan hulle verkondig. Anders as wat met die Israeliete die geval is, gaan die verkondiging nou egter nie oor 'n aardse woonplek nie, maar oor die goeie nuus oor Christus. Die hoor van die nuus is egter nie genoeg nie; dit moet vertrou en gehoorsaam word (Ellingworth, 1991:34).

Die Israeliete het dus geen nut uit die verkondiging geput nie omdat die aanhoor daarvan nie gepaard gegaan het met geloof nie. Die verkondiging moet verenig word met geloof ten einde effektief te wees. Daar is ' $n$ noue band tussen die verkondigde woord en geloof: die verkondigde 
woord bring eers seën as dit in geloof aanvaar word en nie net maar bloot gehoor word nie (Stedman, 1991:55). So 'n verkondiging kan eintlik as tevergeefs gesien word (Du Toit, 1954:117).

Aan die lesers en die skrywer van die brief is die boodskap eenmaal gebring, maar die nawerking duur ook steeds voort. Die saak is dat die verkondigde woord geen effek het as dit nie in geloof aangehoor word nie (soos in die geval van Israel), al word dit sonder ophou aangehoor. As die boodskap in die geloof aangehoor word, het die langdurige aanhoor daarvan die ingang tot ook die ewige rus tot gevolg (DeSilva, 2000:156-158).

Dit gaan nie hier net om die formele verkondiging van die Woord nie, maar oor die aanhoor van die blye boodskap in geloof, op welke wyse ook al.

\section{Basisteoretiese afleiding}

- Selfs volgehoue verkondiging het geen effek as dit nie met die geloof verenig en toegeëien word nie.

- Die verkondiging van hoop moet gepaard gaan met voorbidding om geloofsversterking en groei vir die traumalyer.

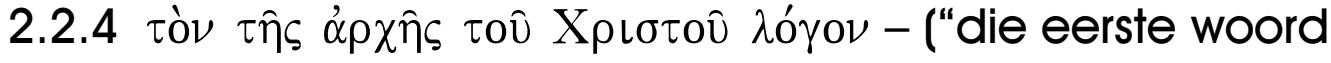
aangaande Christus'" - Hebreërs 6:1

"Die begin van die prediking aangaande Christus ..." Die skrywer van die brief verduidelik aan die Hebreërs die noodsaaklikheid daarvan om voortdurend te groei in die geloof ten einde volwasse en sterk te word in die geloof. Hierin noem hy dan dat hulle nie moet bly by die eerste dinge wat aangaande Christus aan hulle verkondig is nie. Hulle kan egter nooit die eerste sake wat oor Christus verkondig is ontken nie; dit het wel waarde, maar dit is verkeerd om daarby te bly staan (Stedman, 1991:6869).

Dit impliseer dan dat die skrywer homself gedwonge voel om nou verder te gaan, en om vaste kos aan die Hebreërs te bied. Die skrywer self pas nou sy eie raad toe deur nie weer 'n verduideliking van die eerste sake te gee nie. Hy self pas die saak toe deur dieper sake van die geloof aan hulle te verkondig, soos hy in hoofstuk 7 doen deur te preek oor die priesterorde van Melgisedek (Stedman, 1991:68; DeSilva, 2000:215216).

Du Toit (1954:150) maak die volgende stelling in hierdie verband oor die aard van die verkondiging soos afgelei uit Hebreërs: "Ja, ons tyd het groot behoefte aan die vermaning van die skrywer van die brief aan die 
Hebreërs in hoofstuk 6:1. Die nood van ons tyd roep met luide stem om herlewing op die kansel en in die kerkbanke."

Dit is dus nie goed om in die verkondiging net by die fundamentele sake van die geloof te bly staan nie. Dit kan lei tot geestelike traagheid en agteruitgang. Die geloof neem toe in groei as kennis oor die inhoud daarvan toeneem (Stedman, 1991:71).

\section{Basisteoretiese afleiding}

- Verkondiging moet verder gaan as die basiese geloofsbeginsels ten einde ware geloofsgroei tot gevolg te hê.

- Die traumalyer moet ook bedien word vanuit die rykdom van die Skrif. Deur byvoorbeeld van Kategismusprediking gebruik te maak word alle aspekte van die geloof gedek vanuit 'n troosvolle benadering.

\subsubsection{Samevatting}

In die Hebreërpreek word die volgende afleidings gemaak oor verkondiging:

- Christus was die eerste wat die groot saligheid op aarde aan die mense verkondig het.

- Die feit dat Hy die eerste verkondiger daarvan is, maak die saligheid soveel meer heerlik en betroubaar. Juis daarom bied die verkondiging van die groot saligheid soveel meer hoop aan getraumatiseerdes.

- Jesus sien Homself in sy verkondiging as broer van dié aan wie Hy verkondig. Hy staan nie in 'n kliniese afstandsverhouding nie, maar in 'n verhouding soos dié van 'n broer: innig en op dieselfde vlak.

- Verkondiging wat die voorbeeld van Christus volg, geskied op intieme wyse, waar verkondiger en hoorder op gelyke vlak verkeer.

- Dit is belangrik dat die verkondiger hoop moet bedien vanuit 'n naby verhouding met die traumalyer.

- Selfs volgehoue verkondiging het geen effek as dit nie met die geloof verenig en toegeëien word nie.

- Die verkondiging van hoop moet gepaard gaan met voorbidding om geloofsversterking vir die traumalyer.

- Verkondiging moet verder gaan as die basiese geloofsbeginsels, ten einde ware geloofsgroei tot gevolg te hê.

- Die traumalyer moet bedien word vanuit die rykdom van die Skrif. Kategismusprediking betrek byvoorbeeld al die aspekte van die geloof vanuit ' $n$ benadering van troos en bemoediging. 


\section{Basisteoretiese perspektiewe uit Hebreërs op hoop}

3.1 Kernbegrippe/omskrywings wat gebruik word met betrekking tot hoop in die Hebreërspreek

- $\tau \hat{\eta} \varsigma$ '́ $\lambda \pi i ́ \delta o \varsigma$ - (“die hoop”) - Hebreërs 3:6

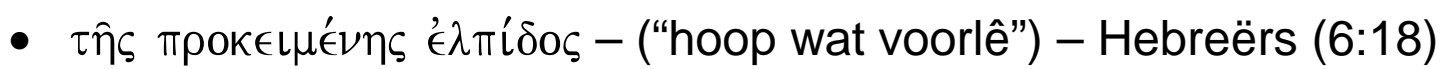

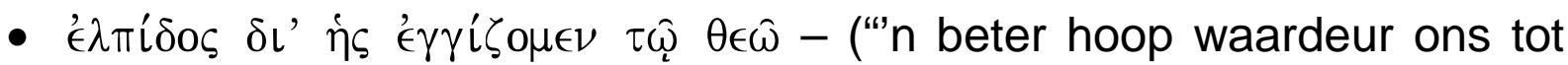
God nader") - Hebreërs (7:19)

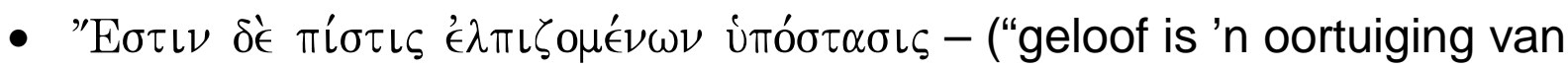
hoop") - Hebreërs (11:1)

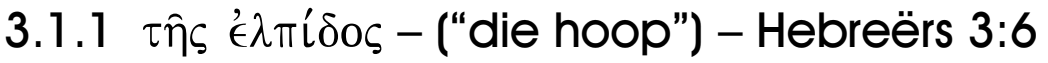

In hierdie gedeelte is die skrywer besig om Moses en Christus versigtig te vergelyk en te kontrasteer. Moses was dienaar in die huishouding van God, maar Christus is die Seun in die huishouding - Hy is dus soveel meer (Stedman, 1991:48-49). In die tweede helfte van vers 6 omskryf die skrywer dan wie die huishouding uitmaak. Hy skryf "Ons is sy huis" (1953-vertaling). Ellingworth (1991:29) voer aan dat ons daarop moet let dat deelwees van hierdie huishouding nie outomaties is nie.

Die tabernakel word ten minste ses keer in die Ou Testament "die huis van God" genoem, en na die tempel word 43 keer verwys as die huis van God (Stedman, 1991:48). Volgens Stedman (1991:49) is die tema van die "huisgesin van God" oorheersend in Hebreërs. Die skrywer van Hebreërs gebruik reeds die taal van 'n huisgesin in 2:10: “... wou baie as sy kinders tot heerlikheid lei". Weereens word verwys na die huisgesin van God in 10:21 "En terwyl ons Hom ook as groot priester oor die huis van God het ..."

DeSilva (2000:132) bou die gedagte van die gemeente as huisgesin van God uit. Hy meen dat die siening dat die Christene van die vroeë kerk hulleself as naasbestaandes van mekaar beskou het, wyd aanvaar is. Hierdie vroeë Christene se geboorte as deel van God se huisgesin het aan hulle 'n nuwe status gegee, nuwe familie en hoop op 'n nuwe erfdeel. Die etos van hierdie nuwe gesinsverhouding tussen gelowiges, en die verantwoordelikhede wat daarmee gepaard gaan, was 'n groot bron vir die bevestiging van die Christene se status en om gelowiges aan te spoor tot hulp aan mekaar. Die skrywer van Hebreërs gebruik deurgaans hierdie beeld om die identiteit van sy gehoor te bevestig. Dit is vanuit hierdie identiteit wat hulle hul verantwoordelikhede tot mekaar en gegrond in die broederlike liefde (13:1-3) moet verstaan en nakom. 
Dit blyk hier noodsaaklik te wees om die gemeente toe te rus met die wete dat hulle as lede van die een huisgesin van God, toegerus deur sy Woord en Gees, mekaar moet toerus en versterk. So is die bemoediging en versterking van die traumalyer met Christelike hoop die verantwoordelikheid van die hele gemeente as lede van een gesin.

Die hoop in die huisgesin is iets waaraan vasgehou moet word met moed en oortuiging. Hierdie moed en oortuiging word gebore vanuit die hoop. Die voordele wat ons deur die Seun in die huishouding het, lê deels nog in die toekoms, en daarom is dit 'n saak van hoop. Alles hang dan af van die uithouvermoë (Ellingworth, 1991:30). Die versekering van deelwees van die huishouding van God is dus geleë in die vasberade hoop.

Die skrywer van die brief moedig sy lesers aan om vas te hou aan die hoop. Hulle moet 'n besluit neem om daaraan vas te hou op grond daarvan dat Jesus, die Seun in die huishouding, soveel meer is as wat Moses die dienaar was. Die werk van Jesus is dus soveel meer betroubaar. Dit gaan hier uiteindelik oor die besluit om standvastig te wees in die hoop tot aan die einde wanneer die geloof ons weer sal vashou (Crouch, 1983:76). Die aoristus-tyd van $\kappa \alpha \tau \alpha ́ \alpha \chi \omega \mu \epsilon \nu$ dui op die idee van 'n baie stywe greep, 'n aksie waarop besluit is eens en vir altyd. Ons sal daarom altyd vashou, maar dit dui hier spesifiek op die besluit van die handeling om vas te hou aan die hoop (Crouch 1983:81).

Hierdie hoop is die kenmerk van die Christelike lewe, omdat die Christen uitsien na die volle heerlikheid in Christus, wat nie in hierdie wêreld te vinde is nie. So 'n hoop is nie ' $n$ vermoede nie, maar 'n gewisse sekerheid oor dit wat nog nie aanwesig is nie.

Die begrip $\tau \hat{\eta} \varsigma$ '́ $\lambda \pi i ́ \delta$ os impliseer dus 'n voorwaarde, nie om te sê wat ons moet doen nie, maar om te benadruk dat dit iets is waaraan ons kan meet of ons aan die huisgesin van God behoort. Die hoop gee vrymoedigheid, en ons weet ons is lidmate van God se huis as ons dan vashou aan die vrymoedigheid en oortuiging van ons hoop.

\section{Basisteoretiese afleiding}

- Die verkondiging van hoop aan traumalyers het vrymoedigheid en oortuiging van geloof tot gevolg.

- Die gelowiges as lidmate van die huisgesin van God met gemeenskaplike hoop, dra die verantwoordelikheid om mekaar, en veral die traumalyer, te bedien met broederlike liefde. 
- Die vrymoedigheid en oortuiging wat hoop tot gevolg het, is 'n bewys dat die traumalyer deel is van die huisgesin van God. Dit dien as bemoediging en troos vir die traumalyer.

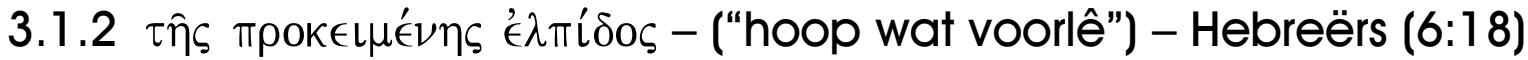

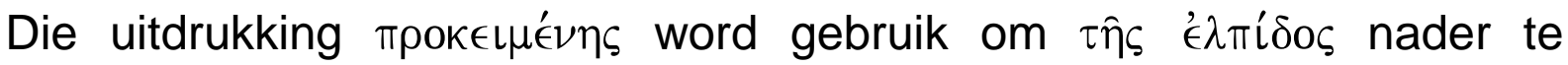

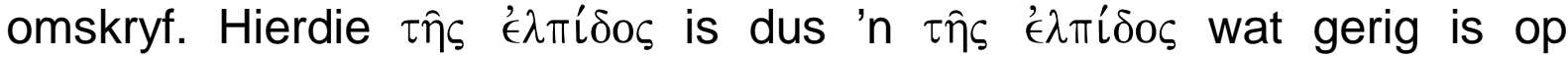
$\left.\pi \rho \epsilon_{\epsilon} \mu \epsilon \in \eta\right\rceil$, naamlik dit wat voorlê. Die saamtrekpunt van Hebreërs 6:13-19 is geleë in die gedagte dat ons aangespoor word om vas te hou aan die hoop, op grond daarvan dat God met 'n eed en 'n belofte getuig dat Hy sy woord gestand sal doen. Al wat die mens het, is hoop op God se belofte en sy eed dat ons deel het aan die saligheid deur Christus. Die krag van die hoop is daarin geleë dat dit God is wat belowe het en 'n eed afgelê het. Vers 19 gaan verder en lewer 'n waardevolle perspektief op hierdie hoop.

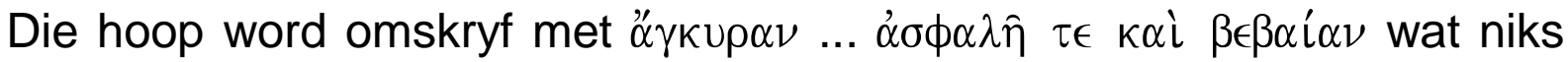
anders suggereer nie as ' $n$ boot se anker wat veilig en stewig is. In plaas daarvan dat die anker van hoop in die bodem vas is, soos 'n skip se anker, is hierdie anker in die hemel vas, in Christus en die rykdom wat Hy bewerk (DeSilva, 2000:251).

Die belofte van God spoor ons aan om vas te hou aan die hoop wat ons in Christus het. En Christus is reeds by die Vader; daarom is ons hoop reeds volbring en gevestig. Maar $\pi \alpha \rho \alpha ́ k \lambda \eta \sigma \iota \nu$ wys op meer as net aansporing of vermaning. Dit dui ook op troos. Daar is troos in God se belofte, sowel as 'n vermaning tot standvastigheid.

DeSilva (2000:250) meen dat die oortuigings- en vermanende krag van dié perikoop nie in die inhoud van die hoop lê nie, maar in die hoop op sigself wat rus op God se beloftes. Die vermaning tot hoop op God se beloftes is die doel van die perikoop. Die hoop is die anker vir die mens, dit is die waarborg, die belofte. Die gelowiges word in hul omstandighede gemaan om aan die hoop vas te hou, want die hoop is seker op grond van God se beloftes. 'n Verwerping van die hoop sou impliseer dat God se eie woorde as onbetroubaar en leuenagtig gereken word.

Die inhoud van die hoop wat dan nou voorlê, is dit dat ons in Christus 'n volkome verlossing sal hê waardeur ons aan die binnekant van die voorhangsel tot by die onmiddellike nabyheid van God kan kom terwyl ons hier op aarde woon. Dit is die hoop waaraan die gelowiges moet vashou (DeSilva, 2000:250). Hierdie hoop word in die evangelie aan die mens voorgehou. Die hoop word aan die mens voorgehou as toevlug wanneer hy voel dat hy in doodgevaar is. Die hoop word hier vergelyk 
met die beeld van die skip se anker (Stedman, 1991:77, 78). In die beproewinge van hierdie lewe kan die gelowige se hart en gedagtes kalm wees, solank sy hoop in die hemel (Christus en sy werk) stewig geanker is.

Crouch (1983:150) vat vers 18 saam deur twee stellings. 1) Hoop berus op God se belofte - iets wat geduld vra. 2) Hoop berus op God se eed wat die grond is vir sekerheid. Ook wys hy daarop dat die praesens aktief van " $\chi \chi \mu \epsilon \nu$ dui op die langdurige, onafgebroke en konstante van die hoop waarheen ons vlug.

\section{Basisteoretiese afleiding}

- Die hoop wat vastigheid skenk aan die getraumatiseerde, is 'n vertroue op God se belofte en eed oor die weldade in en deur Christus weldade wat altyd geldig is.

- Die getraumatiseerde se hoop op die werk van Christus is soos 'n anker wat hy in die hemel het.

- God self spoor almal, ook die getraumatiseerde, aan om te hoop op grond van God se belofte en eed.

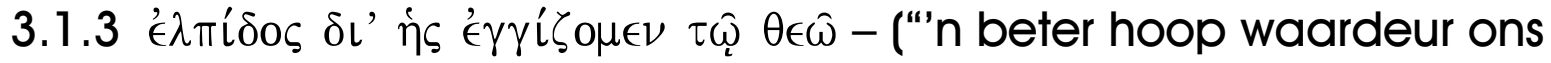 tot God nader") - Hebreërs (7:19)}

"... hoop waardeur julle tot God nader": Die grammatika van die sin toon aan dat die skrywer besig is om heen te wys na Christus as die inhoud van die hoop (Ellingworth, 1991:58). Die doel van godsdiens is om nader aan God te beweeg, en dit gebeur deur die hoop. Dit is die vervulling van die doel wat $\epsilon \epsilon \in \epsilon^{\prime} \omega \sigma \in \mathcal{L}$ (volmaaktheid) uiteindelik het. Dit gaan daaroor dat alle grense tussen God en mens verwyder word deur hierdie nuwe hoop, naamlik Christus (Ellingworth, 1991:58).

Die twee woorde ' $\epsilon \nu \tau 0 \lambda \hat{\eta} \varsigma$ en ' $\epsilon \lambda \pi i ́ \delta o \varsigma$ staan hier in sterk kontras teenoor mekaar. Wat die wet nie by magte was om te doen nie, is nou die werk van die hoop (Crouch, 1983:195). Die wet het die gewete skuldig gelaat voor God, en die sonde nie weggeneem nie. Hier word egter van 'n beter hoop gepraat omdat die sekerheid wat dit tot gevolg het, soveel groter is as die sekerheid wat die wet kon bied (Stedman, 1991:84).

Grosheide (1955:173-174) wys duidelik daarop dat die wet reeds van die begin af iets meer geïmpliseer het, omdat die wet nie by magte was om te doen waarvoor dit tot stand gebring is nie. Dit wet het dan uiteindelik die hoop genoodsaak. Die blote hoop op verlossing in Christus ('n mens kan nie hoop sonder geloof nie) is genoeg om reggestel te wees voor 
God. Die hoop herstel ons voor God as rein, en doen dan dit wat die wet veronderstel was om te bewerk.

\section{Basisteoretiese afleiding}

- Wie in hoop tot God te nader, het die bewys dat hy/sy in die regte posisie voor Hom gestel is. Dit geld dus ook vir die getraumatiseerde.

- Hoop hou in dat die getraumatiseerde, soos enige ander gelowige, se onvermoë om sondeloos te lewe nie tussen hom en God kan kom nie, slegs sy gebrek aan hoop.

\subsection{4 "E van hoop") - Hebreërs (1 1:1)}

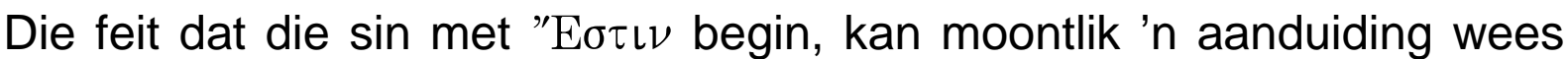
dat iets soos 'n definisie ingelei word (Rienecker \& Rogers, 1980:706; Montefiore, 1964:186) of dat dit bloot gedoen word om die predikaat te beklemtoon. Hierdie beklemtoning dui op die besondere sekerheid oor die onderlinge verband tussen die onderwerp en die predikaat. Daar kom ook geen lidwoorde voor nie, en dit dra by tot die belangrikheid van elke woord. Niks is dus oorbodig nie.

Die waarheid van die stelling word op besondere wyse bevestig. Die implikasie hiervan is dat die sin nie byvoorbeeld sou lui: "Daar is iets soos geloof wat so en so is" nie. Dit is eerder iets soos: "Die geloof waarvan ék praat, het hiérdie en hiérdie eienskappe en aard."

In bogenoemde frase het geloof twee komplemente, naamlik die sekerheid van hoop en die oortuiging van ongesiene dinge. (Ons bepaal ons by die eerste waarin die hoop voorkom - Stedman, 1991:117). Die verband tussen hoop en geloof kan soos volg beskryf word: 'n standvastige versekering van die realiteit van sake wat, terwyl dit in die toekoms lê, voorwerpe van hoop is. Geloof is'n standvastige sekerheid van die realiteit van sake waarop gehoop word, maar wat nog nie gesien kan word nie.

Die persoon wat glo, het sekerheid oor dinge waarop hy hoop, en hierdie dinge is spesifiek sake oor die toekoms. Geloof is 'n vaste sekerheid dat die hoop uiteindelik op iets sal uitloop (Grosheide, 1955:257). Hierdie vaste hoop vind sy oorsprong in die belofte van God self, naamlik dat die heerlikheid nog voorlê.

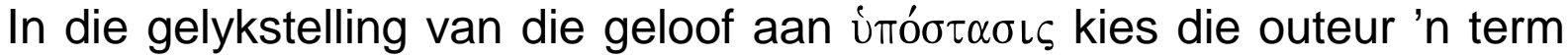

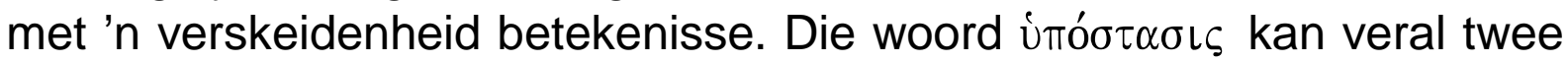
betekenisse hê. Eerstens as 'n filosofiese begrip van "inhoud" of "onderliggende wese" en andersins as regsterm wat verwys na 'n "titelakte" of 
"waarborg" (DeSilva, 2000:383; Danker, 2000:1040-1041; Moulton \& Milligan, 1930:661-660).

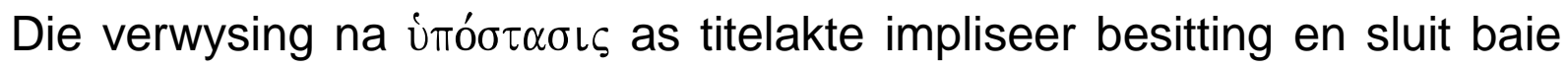
sterk aan by 10:34 waar die geadresseerdes aardse besitting van hulle af weggeneem is. Hierdie hoop word aan hulle voorgehou as die ware besitting wat nie van hulle af weggeneem kan word nie (DeSilva, $2000: 383$ ). Hoop is 'n besitting van die gelowige, 'n vergoeding vir alles wat opgeoffer moet word in hierdie lewe.

\section{Basisteoretiese afleiding}

- Die inhoud van hierdie hoop berus op dinge wat nog voorlê, naamlik dit wat ons in Christus gaan ontvang. Dit is wat aan die getraumatiseerde verkondig moet word.

- 'n Vaste hoop is een van die eienskappe van geloof.

- Hierdie hoop is die waarborg dat ons die geloof besit op grond van dit wat ons hoop. Hoop as waarborg van God se genade en lewe in Christus is ook die besit van die traumalyer.

\subsubsection{Samevatting}

In Hebreërs word die volgende afleidings oor hoop gemaak:

- Die verkondiging van hoop aan traumalyers het vrymoedigheid en oortuiging van geloof tot gevolg.

- Die gelowiges as lidmate van die huisgesin van God en met gemeenskaplike hoop, dra ' $n$ verantwoordelikheid om mekaar te bedien met broederlike liefde, veral ook 'n verantwoordelikheid teenoor die traumalyer.

- Die vrymoedigheid en oortuiging wat hoop tot gevolg het, is 'n bewys dat die traumalyer deel is van die huisgesin van God. Dit dien as bemoediging en troos vir die traumalyer.

- Die hoop wat vastigheid skenk aan die getraumatiseerde, is 'n vertroue op God se belofte en eed oor die weldade in en deur Christus - weldade wat altyd geldig is.

- Die getraumatiseerde se hoop op die werk van Christus is soos 'n anker wat hy in die hemel het.

- God self spoor almal, ook die getraumatiseerde, aan om te hoop op grond van God se belofte en eed.

- Wie in hoop tot God te nader, het die bewys dat hy/sy in die regte posisie voor Hom gestel is. Dit geld ook vir die getraumatiseerde. 
- Hoop hou in dat die getraumatiseerde, soos enige ander persoon, se onvermoë om sondeloos te lewe nie tussen hom en God kan kom nie - slegs sy gebrek aan hoop.

- Die inhoud van hierdie hoop berus op dinge wat nog voorlê, naamlik dit wat ons in Christus gaan ontvang. Dít is wat aan die getraumatiseerde verkondig moet word.

- 'n Vaste hoop is een van die eienskappe van geloof.

- Hierdie hoop is die waarborg dat ons die geloof in dit waarop ons hoop, werklik besit. Hoop as waarborg van God se genade en lewe in Christus is ook die besit van die traumalyer.

\section{Metateoretiese perspektiewe op trauma}

\subsection{Die aard van trauma}

Psigologiese trauma het veel meer oorsake as net geweld of misdaad. Trauma kan ook veroorsaak word deur byvoorbeeld natuurrampe, natuurlike dood of finansiële bankrotskap (Joseph, Williams \& Yule, 1997:51-67).

"Beauty lies in the eye of the beholder" (and so does trauma!). Dié Engelse spreekwoord impliseer dat die oordeel oor skoonheid afhang van die individu wat daarna kyk, dit ervaar, dit interpreteer, en dit uiteindelik beoordeel. Elke individu het dus 'n unieke, eie raamwerk waarbinne beoordeling plaasvind. Vanuit hierdie raamwerk word die objek dan uiteindelik as 'n beeld van skoonheid geklassifiseer of nie (Sadock \& Kaplan, 1998:618).

Dit is presies die geval met trauma. Die bepalende faktor wat 'n gebeurtenis as 'n trauma klassifiseer of nie, is die unieke individu se ervaring, interpretasie, en assimilasie van die gebeurtenis. Hierdie verskynsel is algemeen bekend in die amptelike psigiatriese nosologie (siekteleer) (Hyer, 1994:x).

Die mees algemene reaksies op trauma is onder andere angs/vrees, die herbelewing van die gebeure, ongeduld/irritasie, vermyding/ontkenning, aggressie/woede, skaamte-/skuldgevoelens, mismoedigheid/uitsigloosheid, negatiewe self- en werklikheidsbeelde, wantroue en substansmisbruik (Foa, 2001:01).

\subsection{Posttraumatiese stres (PTS) en Posttraumatiese stressindroom (PTSS)}

Die spanning en simptome wat voortvloei uit 'n traumatiese gebeurtenis kan benoem word as Posttraumatiese Stres (PTS). Hierdie tipe stres is 
algemeen en word in die alledaagse lewe aangetref. 'n Voorbeeld hiervan is as iemand dalk in 'n motorongeluk betrokke is, daarna bewerig by die huis kom en suikerwater drink. So 'n persoon mag dalk aanvanklik huiwerig wees om weer in 'n motor te klim, maar na 'n maand funksioneer die persoon weer normaal en lê die hele gebeurtenis in die verlede. Die stres wat die ongeluk veroorsaak het, het nie 'n buitengewoon langdurige disfunksie en ontwrigting van die persoon se lewe tot gevolg nie.

Maar waar die persoon nie die trauma verwerk nie en daar wel buitengewoon langdurige disfunksie en ontwrigting is, kan posttraumatiese stres as 'n sindroom geklassifiseer word. Dit kan dan gebeur as die persoon in die ongeluk (in die voorbeeld hierbo) nooit weer 'n motor self bestuur nie of selfs nooit weer in 'n motor klim nie. Dit ontwrig die persoon se hele lewe en daaglikse funksionering.

Elke traumatiese ervaring het dus ook 'n noodwendige simptoom. Daar is egter ' $n$ groot verskeidenheid traumatiese gebeure wat verwante simptome deel. As hierdie simptome dan buitengewoon langdurige ontwrigting en disfunksie tot gevolg het, gee dit aanleiding tot 'n psigopatologiese sindroom. Hierdie aanname word algemeen aanvaar in die "Diagnostic and Statistical Manual of Mental Disorders - IV" (DSM-IVTR, 2000). Hierdie handleiding is dié standaardriglyn waarvolgens psigoloë in Amerika hul diagnoses vorm. Elke diagnose wat gemaak word, word gemaak binne die raamwerk van hierdie riglyn deur die Amerikaanse Psigiatriese Assosiasie (APA).

Dit impliseer dat daar 'n enkele psigopatologiese eindpunt bestaan, onafhanklik daarvan of die traumatiese gebeurtenis verkragting, oorlog, 'n motorongeluk, of die aanskoue van 'n gruweldood was. Hierdie psigopatologiese sindroom staan bekend as 309.81 Posttraumatiese Stres Sindroom (PTSS). Die kode verwys na die "International Classification of Diseases", ook bekend as die ICD-9-CM-kode. Die mens se gevoelsreaksies op 'n wye verskeidenheid traumatiese gebeure kan dus deur hierdie internasionaal aanvaarde sindroom benoem word, op grond van die onmiskenbare ooreenkomste in die onderskeie voortdurende en ontwrigtende simptome (McFarlane et al., 2000:11).

\subsection{PTSS nader verklaar}

PTSS word in die Sielkunde as 'n unieke versteuring beskou, want een van die duidelike kriteria waarvolgens dit gediagnoseer word, is ook die primêre etiologiese (oorsaaklike) faktor, naamlik 'n traumatiese gebeurtenis. Sonder hierdie traumatiese gebeurtenis kan PTSS nie bestaan nie. Ten spyte van hierdie duidelike kriteria in die benaming is daar telkens 
verander aan die definisie van PTSS, soos duidelik blyk uit die opeenvolgende uitgawes van die APA se DSM.

Die huidige definisie in die DSM-IV lui soos volg:

Posttraumatic Stress Disorder is characterized by the reexperiencing of an extremely traumatic event accompanied by symptoms of increased arousal and by avoidance of stimuli associated with the trauma (DSM-IV-TR, 2000: 429).

Die kriteria vir die diagnose van PTSS help om die definisie te verduidelik. Daar moet aan hierdie kriteria voldoen word alvorens 'n diagnose van PTSS gemaak kan word. Hier onder volg die kriteria soos aangehaal uit die DSM-IV (DSM-IV-TR, 2000:467-468; Sadock \& Kaplan, 1998:619):

(A) The person has been exposed to a traumatic event in which both of the following were present:

(1) the person experienced, witnessed, or was confronted with an event or events that involved actual or threatened death or serious injury, or a threat to physical integrity of others.

(2) the person's response involved intense fear, helplessness, or horror.

(B) The traumatic event is persistently reexperienced in at least one (or more) of the following ways:

(1) Recurrent and intrusive distressing recollections of the event, including images, thoughts, or perceptions. Note: In young children, repetitive play may occur in which themes or aspects of the trauma are expressed.

(2) Recurrent distressing dreams of the event. Note: In children, there may be frightening dreams without recognizable content.

(3) Acting or feeling as if the traumatic event were recurring (includes as sense of reliving the experience, illusions, hallucinations, and dissociative flashback episodes, including those that occur on awakening or when intoxicated). Note: In young children, traumaspecific reenactment may occur.

(4) Intense psychological distress at exposure to internal or external cues that symbolize or resemble an aspect of the traumatic event. 
(5) Physiological reactivity on exposure to internal or external cues that symbolize or resemble an aspect of the traumatic event.

(C) Persistent avoidance of stimuli associated with the trauma and numbing of general responsiveness (not present before the trauma), as indicated by three (or more) of the following:

(1) efforts to avoid thoughts, feelings, or conversations associated with the trauma

(2) efforts to avoid activities, places or people that arouse recollections of the trauma

(3) inability to recall an important aspect of the trauma

(4) markedly diminished interest or participation in signifycant activities

(5) feeling of detachment or estrangement from others

(6) restricted range of affect (e.g., unable to have loving feelings)

(7) sense of a foreshortened future (e.g., does not expect to have a career, marriage, children, or a normal life span)

(D) Persistent symptoms of increased arousal (not present before the trauma), as indicated by two (or more) of the following:

(1) difficulty falling or staying asleep

(2) irritability or outbursts of anger

(3) difficulty concentrating

(4) hypervigilance

(5) exaggerated startle response

(E) Duration of the disturbance (symptoms in Criteria B, C, and D) is more than one month

(F) The disturbance causes clinically distress or impairment in social, occupational, or other important areas of functioning Specify if:

Acute: if duration of symptoms is less than 3 months Chronic: if duration of the symptoms is 3 months or more Specify if:

With delayed onset: if onset of symptoms is at least 6 months after the stressor. 


\subsection{Die proses van PTS en die ontwikkeling daarvan tot PTSS}

Scott en Stradling verduidelik posttraumatiese stres en die ontwikkeling daarvan tot sindroom aan die hand van 'n skematiese voorstelling soos eerste gebruik deur Alexander, C. McFarlane et al. (Scott \& Stradling, 1992:5).

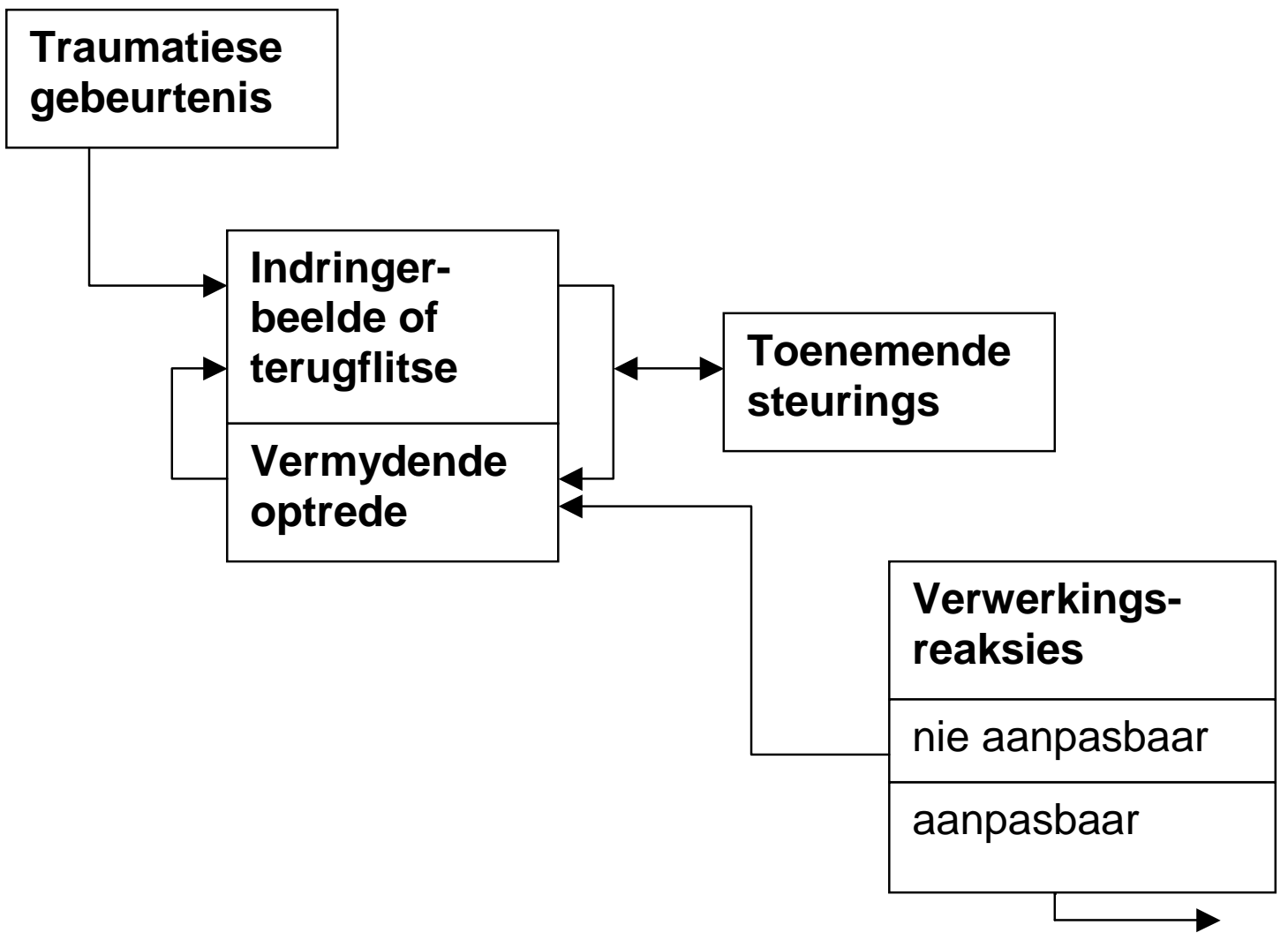

Die traumatiese gebeurtenis (Kriteria A) lei na indringerbeelde of terugflitse (Kriteria B). Dit lei noodwendig na vermydende optrede (Kriteria C) om situasies te vermy wat die beelde weer kan herroep en wat toenemende steurings (Kriteria D) tot gevolg het (vgl. p. 43 en 44).

Dus kan dit wees dat 'n vrou wat verkrag is, geteister word met indringerbeelde of flashbacks van die aanval. In 'n poging om hierdie terugflitse te minimaliseer vermy sy kontak met mans. Die vermydende optrede mag wel die terugflitse minimaliseer, maar as sy skielik onvermydelik in die nabyheid van ' $n$ man is, is dit moontlik dat die terugflitse kan verhoog. Daar is dus ' $n$ wisselwerking tussen die terugflitse en die vermydende optrede. Dit kan lei na toenemende steurings (Kriteria D), wat weer die terugflitse kan vermeerder. Hier is dus ook 'n wisselwerking.

Of die PTS gaan ontwikkel tot PTSS hang af van die doeltreffendheid van die individu se verwerkingsreaksie. As die individu byvoorbeeld sterk drank sou begin misbruik ter verwerking van die trauma of die ontwrigting van die gevolge daarvan ontken, sal die simptome steeds voort- 
duur, al is die ervaring daarvan verdoof of onderdruk (Scott \& Stradling, 1992:5).

As die reaksie egter is om hulp te soek en te poog om terug te keer na "lewe voor die trauma", is daar 'n groter kans dat die toestand verbeter kan word en die siklus, wat die sindroom kenmerk, kan dan verbreek word. Nie-aanpasbare reaksies voed dus die bose kringloop verder, terwyl aanpasbare reaksies uit die kringloop breek en 'n uitkoms bied. Hierdie skematiese voorstelling help om die proses van PTS en die ontwikkeling daarvan tot PTSS te verduidelik.

\subsection{Simptome en gevolge van PTS en PTSS}

Die simptome stem in albei gevalle ooreen, soos die kriteria in die DSMIV dit stel, maar die gevolge van die simptome verskil. Die simptome by PTS dra minimale gevolge, omdat dit tydig verwerk word. Die simptome by PTSS daarteenoor word nie verwerk nie, en duur dan buitengewoon lank. Hierdie voortsetting van die simptome het dan ernstige ontwrigting en disfunksie tot gevolg. Soos reeds genoem, is dit op grond hiervan dat 'n onderskeid getref word tussen PTS en PTSS.

Vir die doeleindes van hierdie artikel word gefokus op die simptome eerder as die gevolge daarvan omdat die uiteindelike doelwit die voorkoming van die gevolge is.

\subsection{Die mees algemene simptome omskryf}

'n Paar van die mees algemene simptome, soos hierbo vermeld, word deur Foa (2001:1), en ander vermeld, naamlik: angs/vrees, aggressie/ woede, skaamte of skuldgevoelens, mismoedigheid of uitsigloosheid, negatiewe self- of werklikheidsbeelde, en substansafhanklikheid.

\section{- Angs/vrees}

Dit kom voor sodra persepsies van die wêreld en die persoon se sin van veiligheid verander, veral na 'n traumatiese ervaring. So ' $n$ individu is dus ontnugter en moet eers weer 'n nuwe persepsie van die wêreld en ook 'n sin vir veiligheid ontwikkel. Die vrae wat die individu hier moontlik teister is: "Hoe lyk die wêreld regtig" en "Wanneer is ek regtig veilig".

\section{- Aggressie/woede}

Die aggressie en woede kan moontlik spruit uit die basiese gevoel dat die wêreld onregverdig is. Soms is die persoon aggressief weens hoë irritasievlakke. Dit kan wel voorkom by mense wat nie gewoonlik aggressiewe neigings het nie. 


\section{- Skaamte- of skuldgevoelens}

Sommige persone blameer hulself vir die dade wat hulle gedoen het, of nie gedoen het nie, om te oorleef. Hulle kyk terug en is teleurgestel in hul optredes. Dit gebeur ook soms dat hulle deur ander persone geblameer kan word vir wat gebeur het.

\section{- Mismoedigheid of uitsigloosheid}

Die persoon het selfverwyt en sê byvoorbeeld: "As ek nie so 'n swakkeling of dom was nie, sou dit nie met my gebeur het nie." Hieruit vloei ook wantroue van die self en ander. Niks of niemand is dus volgens die persoon meer betroubaar nie

\section{- Substansafhanklikheid}

Dikwels word ontvlugting gesoek na die afloop van 'n traumatiese gebeurtenis of denkpatrone wat daaruit ontwikkel het. Dit het dan allerlei substansmisbruike tot gevolg wat moontlike verslawing inhou.

Al hierdie simptome is onderling verbind en kan aanleiding gee tot mekaar. Die simptome kan daarom nie altyd klinkklaar onderskei word nie. Daarom moet opgelet word na enige van bogenoemde reaksies, asook dié wat soortgelyk is (Foa, 2001:1).

5. Praktykteoretiese perspektiewe op die prediking van hoop aan getraumatiseerdes in die huisgesin van God

- Wat die inhoud van die prediking betref, kan die prediking van die volgende perspektiewe hoop bied aan die getraumatiseerde en aan die gemeente:

- Christus bewerk nie net ons saligheid nie. Hy is ook die eerste verkondiger daarvan. Die feit dat $\mathrm{Hy}$ die saligheid eerste verkondig het, bevestig die vastigheid en betroubaarheid daarvan as fondament van hoop te midde van trauma.

- Selfs volgehoue prediking kan nie hoop aan 'n getraumatiseerde bied as dit nie met geloof verenig en toegeëien word nie. Volgehoue gebed vir die getraumatiseerde om die prediking van hoop toe te eien is noodsaaklik.

- Prediking van hoop aan getraumatiseerdes moet geskied met die wye rykdom van die Skrif as inhoud.

- Gebrek aan hoop - en nie 'n onvermoë om sondeloos te lewe nie vorm 'n versperring tussen 'n getraumatiseerde en God. 
- 'n Getraumatiseerde se hoop funksioneer soos 'n anker wat in die hemel vas gevestig is.

- Hoop en geloof is nou verbind. Geloof funksioneer as 'n titelakte van dit waarop 'n getraumatiseerde hoop.

- Omdat die gemeente die huisgesin van God is, moet hulle deur die prediking toegerus word om getraumatiseerdes as geloofsgenote te ondersteun.

- Die vrug van die prediking van hoop uit die wye rykdom van die Skrif het vrymoedigheid en oortuiging vir die getraumatiseerde as deel van die huisgesin van God.

- Die toespitsing van die prediking op hoop vanuit die Woord moet fokus op elemente wat na vore gekom het in die metateoretiese analise. Die deurlopende gevoelspatroon by getraumatiseerdes is: angs, aggressie, skuldgevoel, en uitsigloosheid.

As voorbeelde van toespitsing van die prediking op die gevoelspatroon kan die volgende dien:

\section{Angs/aggressie:}

- Die prediking van hoop as die anker wat vas is by God.

- Die prediking van hoop as vrymoedigheid om tot God te nader.

Skuldgevoel:

- Hoop as bevestiging dat ons skuld as getraumatiseerdes nie tussen God en ons staan nie, maar wel ons gebrek aan hoop.

\section{Uitsigloosheid:}

- Die prediking van geloof as titelakte bied vastigheid in tye van trauma.

- Die prediking aan getraumatiseerdes moet geskied in die gesindheid van broer onder broers wees, dit wil sê in nederigheid en diensbaarheid, op gelyke vlak.

\section{Bibliografie}

ARMSTRONG, R.S. 1990. The pastor-evangelist in the parish. Louisville : Westminster.

BISBEY, S. \& BISBEY L.B. 1998. Brief therapy for post-traumatic stress disorder. London : Wiley.

CROUCH, O.L. 1983. Expository preaching and teaching. Hebrews. Missouri : College Press. 
DANKER, F.W. 2000. A Greek-English lexicon of the New Testament and other early Christian literature. 3de Uitgawe. Chicago : The University of Chicago Press.

DESILVA, D.A. 2000. Perseverance in gratitude. A socio-rhetorical commentary on the epistle "to the Hebrews". Grand Rapids : Eerdmans.

DSM-IV-TR, 2000. Diagnostic and statistical manual of mental disorders - IV Edition - text revision. Washington: American Psyciatric Association.

DU TOIT, G.D. 1954. Die brief aan die Hebreërs. Kaapstad : Christenstudenteverenigingmaatskappy.

ELLINGWORTH, P. 1991. The epistle to the Hebrews. Epworth commentaries. London : Epworth.

FOA, E.B. 2001. Common reactions to trauma. Department of Psychiatry, University of Pennsylvania. [Web:]

http://www.ncptsd.org/facts/disasters/fs_foa_handout.html[Datum van toegang: April 2002].

GROSHEIDE, F.W. 1955. Commentaar op het Nieuwe Testament. De brief aan de Hebreeën en de brief van Jakobus. Kampen : Kok.

HOWARD, L. 2000. EMDR and psychotherapy integration: theoretical and clinical suggestions with focus on traumatic stress. Boca Raton : CRC.

HYER, L. 1994. Trauma victim. Theoretical issues and practical suggestions. Indiana : Accelerated Development.

JOSEPH, S., WILLIAMS, R. \& YULE, W. 1997. Understanding post-traumatic stress. London : Wiley.

LOUW, D.J. 1985. Sin in lyding. ' $n$ Teologiese besinning rondom kruis en opstanding. Kaapstad : Lux Verbi.

LOUW, D.J. 1994. Illness as crisis and challenge. Guidelines for pastoral care. Halfway House : Orion.

McFARLANE, A.C., SHALEV, A.Y. \& YEHUDA, R. 2000. International handbook of human response to trauma. New York : Kluwer Academic/Pelnum.

MONTEFIORE, H.W. 1964. A commentary on the epistle to the Hebrews. London : Black.

MOULTON, J.H. \& MILLIGAN, G. 1930. The vocabulary of the Greek Testament. London : Hodder \& Stoughton.

KRUGER, F.P. 2002. Prediking en gesindheidsverandering. ' $n$ Prakties-teologiese studie in die lig van Hebreërs. Potchefstroom : PU vir CHO. (Th.D. - proefskrif.)

RIENECKER, F. \& ROGERS, C. 1980. Linguistic key to the Greek New Testament. Grand Rapids : Zondervan.

SADOCK, B.J. \& KAPLAN, H.I. 1998. Synopsis of psychiatry. 8ste uitgawe. Baltimore : Lippincott, Williams \& Wilkins.

SCOTT, M.J. \& STRADLING, S.G. 1992. Counselling for post-traumatic stress disorder. London : Sage.

STEDMAN, R.C. 1991. Hebrews. Leicester : InterVarsity Press.

VAN DYK, A. 2001. HIV AIDS. Care and counselling. A multidisciplinary approach. Cape Town : Pearson Education.

VENTER, C.J.H. 2001. Verklarende prediking. Basisteoretiese elemente uit Hebreërs. In die Skriflig, 35(3):373-388.

\section{Kernbegrippe:}

posttraumatiese stres

trauma

verkondiging van hoop 
Prediking van hoop aan getraumatiseerdes ... Prakties-teologiese perspektiewe in ... Heb.

\section{Key concepts:}

posttraumatic stress

preaching of hope

trauma 